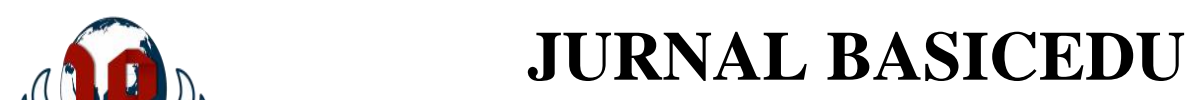

Volume 5 Nomor 3 Tahun 2021 Halaman 1321 - 1328

Research \& Learning in Elementary Education https://jbasic.org/index.php/basicedu

\title{
Penerapan Model Discovery Learning dalam Pembelajaran IPA untuk Meningkatkan Kemampuan Berpikir Kritis dan Hasil Belajar Siswa Sekolah Dasar
}

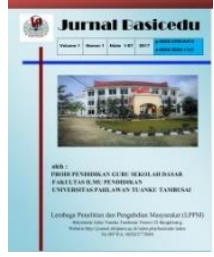

\author{
Wahyu Candra Dwi Safitri ${ }^{1 凶}$, Nani Mediatati² \\ Universitas Kristen Satya Wacana, Indonesia ${ }^{1,2}$ \\ E-mail: wahyucandrads@gmail.com¹ ${ }^{1}$, nani.mediatati@uksw.edu ${ }^{2}$
}

\begin{abstract}
Abstrak
Penelitian tindakan kelas (PTK) ini memiliki tujuan untuk meningkatkan kemampuan berpikir kritis dan hasil belajar siswa klas IV SD Negeri 2 Gunungtumpeng dengan menerapkan model pembelajaran Discovery Learning. Data diperoleh berdasarkan hasil observasi dan tes. Analisis data dilakukan dengan teknik deskriptif komparatif. Subjek penelitian yaitu siswa kelas IV dengan jumlah 24 siswa. Hasil penelitian siklus I menunjukkan bahwa kemampuan berpikir kritis siswa kategori tinggi 3\%, kategori sedang 37\%, kategori rendah $42 \%$, dan kategori sangat rendah $8 \%$. Pada siklus II meningkat yang ditunjukkan dari kemampuan berpikir kritis siswa kategori sangat tinggi 54\%, kategori tinggi 30\%, kategori sedang 8\%, kategori rendah 8\%, dan kategori sangat rendah tidak ada. Ketuntasan hasil belajar pada siklus I yang tuntas KKM ada 3 siswa atau sebesar 13\%, sedangkan siswa yang belum tuntas KKM ada 21 siswa atau sebesar $87 \%$. Siklus II yang tuntas KKM ada 20 siswa atau sebesar 83\%, sedangkan yang belum tuntas KKM ada 4 siswa atau sebesar 17\%. Hasil penelitian menunjukkan bahwa model Discovery learning terbukti dapat meningkatkan kemampuan berpikir kritis dan hasil belajar siswa.
\end{abstract}

Kata Kunci: Discovery learning, kemampuan berpikir kritis, hasil belajar.

\section{Abstract}

Classroom Action Research (CAR) aimed to improve the critical thinking and learning outcomes ability of students in class IV Gunungtumpeng 2 Elementary School by applying the Discovery Learning Model. Data obtained based on the observation and tests. Data were analyzed using a comparative descriptive technique. The research subjects were students grade IV with a total number of 24 students. The results of the first cycle research showed students' critical thinking skills were 3\% high, 37\% moderate, $42 \%$ low, and $8 \%$ very low. In the second cycle, it was indicated by the students' critical ability is $54 \%$ very high category, $30 \%$ high category, $8 \%$ medium category, $8 \%$ low category, and 0\% very low category. The learning outcomes KKM completeness in the first cycle was 3 students or 13\%, while 21 students had not completed the KKM or $87 \%$. In Cycle II, 20 students had completed the KKM or 83\%, while 4 students had not completed the KKM or 17\%. The results showed the Discovery learning model was proven could improve critical thinking skills and student learning outcomes.

Keywords: Discovery learning, critical thinking ability, learning outcomes.

Copyright (c) 2021 Wahyu Candra Dwi Safitri, Nani Mediatati

Corresponding author :

Email : wahyucandrads@gmail.com

DOI $\quad$ : https://doi.org/10.31004/basicedu.v5i3.925 
1322 Penerapan Model Discovery Learning dalam Pembelajaran IPA untuk Meningkatkan Kemampuan Berpikir Kritis dan Hasil Belajar Siswa Sekolah Dasar - Wahyu Candra Dwi Safitri, Nani Mediatati DOI: https://doi.org/10.31004/basicedu.v5i3.925

\section{PENDAHULUAN}

Kemampuan berpikir kritis merupakan salah satu kemampuan berpikir tingkat tinggi dalam memecahkan masalah. (Prameswari et al., 2018) menyatakan bahwa kemampuan berpikir kritis termasuk kemampuan berpikir yang esensial dan berfungsi untuk semua aspek kehidupan. Kemampuan berpikir kritis penting untuk dikembangkan dalam pembelajaran Kurikulum 2013, dimana siswa dituntut untuk aktif dalam pembelajaran dan guru hanya sebagai fasilitator. Namun kenyataannya, masih banyak siswa yang belum terasah kemampuan berpikir kritisnya yang berdampak pada hasil belajar siswa yang kurang optimal.

Berdasarkan hasil wawancara dengan guru kelas IV SD Negeri 2 Gunungtumpeng, siswa cenderung pasif dalam pembelajaran. Hanya dua siswa yang aktif bertanya dan menjawab pertanyaan yang disampaikan oleh guru. Guru sudah menggunakan metode pembelajaran ceramah dan diskusi, namun kemampuan berpikir kritis siswa dalam pembelajaran belum optimal. Selain itu, keterbatasan media pembelajaran yang digunakan oleh guru menjadi kendala bagi siswa terutama dimasa pandemi seperti sekarang dimana pembelajaran dilakukan secara daring.

Dalam rangka mengasah kemampuan berpikir kritis siswa, diperlukan suatu model, metode, strategi maupun pendekatan pembelajaran yang inovatif agar siswa tertarik dan termotivasi dalam mengikuti pembelajaran. Guru yang telah menerapkan suatu model, metode, strategi maupun pendekatan pembelajaran yang dapat mengasah kemampuan berpikir kritis siswa, tentu akan lebih mudah mencapai tujuan pembelajaran secara optimal. Pembelajaran yang menarik dan memotivasi siswa tentu akan bertahan lama pada memori siswa sampai dewasa.

Salah satu model pembelajaran yang cocok dengan Kurikulum 2013 adalah model Discovery learning. (Larasati, 2020) mengatakan bahwa Discovery learning sebagai cara belajar siswa aktif melalui proses menemukan dan menyelidiki sendiri, sehingga hasil yang didapatkan akan bertahan lama dalam ingatan, serta tidak mudah dilupakan oleh siswa. (Ana, 2019) sependapat bahwa Discovery learning merupakan pembelajaran yang tidak diberikan secara keseluruhan, namun siswa mengorganisasi, mengembangkan pengetahuan dan keterampilan untuk pemecahan masalah, sehingga dapat meningkatkan kemampuan penemuan individu dan pembelajaran menjadi berorientasi pada siswa. Sejalan dengan (Fahrurrozi, 2017) yang menyatakan bahwa Discovery learning merupakan cara mengajar yang diatur sedemikian rupa sehingga siswa memperoleh pengetahuan yang sebelumnya belum diketahuinya tidak melalui pemberitahuan, namun sebagian atau seluruhnya ditemukan sendiri.

Melalui belajar penemuan, siswa juga belajar berpikir kritis, analisis, dan mencoba untuk memecahkan masalah yang dihadapi. Selanjutnya siswa yang mampu berpikir kritis dan analitis ini akan berdampak pada hasil belajarnya yang baik pula. Sesuai dengan pendapat (Nurmayani, 2018) menyatakan bahwa hasil belajar merupakan pernyataan spesifik yang diwujudkan dalam bentuk tulisan untuk menyatakan perilaku serta penampilan sebagai gambaran hasil belajar yang diharapkan melalui kegiatan belajar dalam waktu tertentu. Hasil belajar juga diartikan sebagai hasil yang diperoleh seseorang dari suatu aktivitas yang dilakukan serta mengakibatkan terjadinya perubahan tingkah laku (Kristin, 2016). Hasil belajar adalah proses pengumpulan informasi data mengenai capaian pembelajaran siswa yang dilakukan secara terencana dan sistematis guna memantau proses, peningkatan belajar, serta perbaikan hasil belajar melalui penugasan maupun evaluasi hasil belajar (Setianingrum \& Wardani, 2018).

Penelitian (Arfika Wedekaningsih, Henny Dewi Koeswanti, 2019) dengan judul "Penerapan Model Pembelajaran Discovery learning untuk Meningkatkan Kemampuan Berpikir Kritis dan Hasil Belajar Matematika" di SD Negeri Cebongan 03 menunjukkan peningkatan kemampuan berpikir kritis dan hasil belajar siswa kelas IV. Siklus I, kemampuan berpikir kritis dan hasil belajar siswa meningkat menjadi 4,3\% kategori sangat kritis, 21,7\% kategori kritis, 34,8\% kategori cukup kritis, 30,5\% kategori kurang kritis, dan $8,7 \%$ kategori tidak kritis sehingga hasil belajar pada siklus 1 menjadi $52 \%$ tuntas, dan $48 \%$ belum tuntas. 
1323 Penerapan Model Discovery Learning dalam Pembelajaran IPA untuk Meningkatkan Kemampuan Berpikir Kritis dan Hasil Belajar Siswa Sekolah Dasar - Wahyu Candra Dwi Safitri, Nani Mediatati DOI: https://doi.org/10.31004/basicedu.v5i3.925

Selanjutnya pada siklus II mengalami peningkatan kembali dengan 17,4\% kategori kritis sekali, 30,4\% kategori kritis, 43,5\% kategori cukup kritis, dan 8,7\% kategori kurang kritis sehingga hasil belajar meningkat menjadi $87 \%$ tuntas dan $13 \%$ belum tuntas.

Senada dengan penelitian (Maharani \& Hardini, 2017) dengan judul "Penerapan Model Pembelajaran Discovery learning Berbantuan Benda Konkret untuk Meningkatkan Hasil Belajar IPA" yang dilakukan di SD Negeri 3 Kemiriombo Kecamatan Gemawang Kabupaten Temanggung menunjukkan peningkatan hasil hasil belajar siswa kelas IV. Kondisi awal persentase ketuntasan hasil belajar siswa 55\%, rata-rata 69 dengan nilai tertinggi 76 dan terendah 65 . Siklus I, persentase ketuntasan $72 \%$, rata-rata 73 dengan nilai tertinggi 84 dan nilai terendah 64. Selanjutnya pada siklus II, persentase ketuntasan $90 \%$, rata-rata 75 dengan nilai tertinggi 84 dan nilai terendah 66. Selain itu, penelitian (Nurul Istikomah, 2018) dengan judul "Penerapan Model Discovery Learning pada Pembelajaran IPS untuk Meningkatkan Keaktifan dan Hasil Belajar Kognitif Siswa Sekolah Dasar" yang dilakukan di SDN Ngampon juga menunjukkan peningkatan keaktifan dan hasil belajar siswa kelas V. Persentasi kenaikan keaktifan dan hasil belajar kognitif dari pra siklus ke siklus I, siklus II dari $38 \%$ kategori aktif dan hasil belajar kognitif $43 \%$ tuntas, menjadi $86 \%$ kategori aktif dan $68 \%$ tuntas siklus I, menjadi $95 \%$ kategori aktif dan $86 \%$ tuntas siklus II.

Berdasarkan permasalahan yang diuraikan di atas, maka peneliti melakukan penelitian tindakan kelas dengan menerapkan model pembelajaran Discovery learning untuk meningkatkan kemampuan berpikir kritis dan hasil belajar siswa dalam pembelajaran IPA kelas 4 SD.

\section{METODE PENELITIAN}

Penelitian ini termasuk jenis penelitian tindakan kelas (PTK). Penelitian tindakan kelas merupakan kegiatan penelitian ilmiah yang dilakukan oleh tenaga pendidik atau guru untuk meningkatkan atau memperbaiki proses pembelajaran. Penelitian ini mengacu pada model spiral dari Kemmis dan Mc. Taggart. Rencana tindakan dilakukan melalui dua siklus. Setiap siklus terdiri dari empat komponen yakni perencanaan (planning), tindakan (acting), pengamatan (observing), dan refleksi (reflecting). Komponen tindakan (acting) dan pengamatan (observing) dilakukan dalam waktu bersamaan. Penelitian ini dilakukan pada siswa kelas 4 SD Negeri 2 Gunungtumpeng yang berjumlah 24 orang. Siswa laki-laki sebanyak 10 orang, dan siswa perempuan sebanyak 14 orang.

Data yang digunakan dikumpulkan melalui lembar observasi dan soal tes. Lembar observasi digunakan untuk mendapatkan informasi terkait jumlah siswa, jadwal pelajaran, silabus, serta aktivitas guru dan siswa dalam pembelajaran. Soal tes digunakan untuk mengukur kemampuan berpikir kritis dan hasil belajar siswa. Teknik analisis data yang digunakan yakni deskriptif komparatif.

Penelitian yang dilakukan sebanyak 2 siklus ini terdiri dari satu kali pertemuan setiap siklus. Penelitian dikatakan berhasil apabila $\geq 80 \%$ siswa memperoleh nilai hasil belajar tuntas $\mathrm{KKM} \geq 70$ dan mempunyai kemampuan berpikir kritis dalam kategori sangat tinggi dan tinggi.

\section{HASIL DAN PEMBAHASAN}

Berdasarkan data yang diperoleh, terjadi peningkatan rerata nilai kemampuan berpikir kritis dari siklus I ke siklus II. Berikut adalah hasil kemampuan berpikir kritis siklus I yang dapat dilihat pada tabel 1 .

Tabel 1. Hasil Kemampuan Berpikir Kritis Siklus I

\begin{tabular}{|l|c|c|c|}
\hline Kategori & Interval & Frekuensi & Persentase (\%) \\
\hline Sangat Tinggi & $81-100$ & 0 & 0 \\
\hline Tinggi & $61-80$ & 3 & 13 \\
\hline
\end{tabular}


1324 Penerapan Model Discovery Learning dalam Pembelajaran IPA untuk Meningkatkan Kemampuan Berpikir Kritis dan Hasil Belajar Siswa Sekolah Dasar - Wahyu Candra Dwi Safitri, Nani Mediatati DOI: https://doi.org/10.31004/basicedu.v5i3.925

\begin{tabular}{|l|c|c|c|}
\hline Sedang & $41-60$ & 9 & 37 \\
\hline Rendah & $21-40$ & 10 & 42 \\
\hline Sangat Rendah & $1-20$ & 2 & 8 \\
\hline Jumlah & 24 & 100 \\
\hline Kesimpulan & \multicolumn{2}{|c|}{ Belum berhasil } \\
\hline
\end{tabular}

Pada siklus 1 menunjukkan bahwa kemampuan berpikir kritis siswa kategori tinggi 13\%, kategori sedang $37 \%$, kategori rendah $42 \%$, dan kategori sangat rendah $8 \%$, sehingga dapat disimpulkan bahwa tindakan pada siklus 1 ini belum berhasil.

Berdasarkan hasil pembelajaran siklus 1 menggunakan model pembelajaran Discovery learning, diperoleh hasil sebagai berikut.

Tabel 2. Distribusi Frekuensi Hasil Belajar Siklus I

\begin{tabular}{|l|c|c|c|}
\hline Ketuntasan & Interval & Frekuensi & Persentase (\%) \\
\hline Tuntas & $\geq 70$ & 3 & 13 \\
\hline Tidak tuntas & $\leq 69$ & 21 & 87 \\
\hline KKM & \multicolumn{3}{|c|}{70} \\
\hline Nilai terendah & \multicolumn{3}{|c|}{20} \\
\hline Nilai tertinggi & 80 \\
\hline
\end{tabular}

Hasil belajar siswa kelas 4 SD Negeri 2 Gunungtumpeng pada siklus 1 yang tuntas KKM adalah 3 siswa atau sebesar 13\%, sedangkan siswa yang belum tuntas KKM adalah 21 siswa atau sebesar $87 \%$.

Selanjutnya pada siklus II diperoleh hasil kemampuan berpikir kritis siswa sebagai berikut:

Tabel 3. Hasil Kemampuan Berpikir Kritis Siklus II

\begin{tabular}{|l|c|c|c|}
\hline Kategori & Interval & Frekuensi & Persentase (\%) \\
\hline Sangat Tinggi & $81-100$ & 13 & 54 \\
\hline Tinggi & $61-80$ & 7 & 30 \\
\hline Sedang & $41-60$ & 2 & 8 \\
\hline Rendah & $21-40$ & 2 & 8 \\
\hline Sangat Rendah & $1-20$ & 0 & 0 \\
\hline Jumlah & 24 & 100 \\
\hline Kesimpulan & \multicolumn{3}{|c|}{ Berhasil } \\
\hline
\end{tabular}

Pada siklus II menunjukkan bahwa kemampuan berpikir kritis siswa kategori sangat tinggi 54\%, kategori tinggi $30 \%$, kategori sedang $8 \%$, kategori rendah $8 \%$, dan kategori sangat rendah tidak ada, sehingga dapat disimpulkan bahwa tindakan pada siklus II ini berhasil.

Berdasarkan hasil belajar siswa pada siklus II menggunakan model pembelajaran Discovery learning, diperoleh hasil sebagai berikut.

Tabel 4. Distribusi Frekuensi Hasil Belajar Siklus II

\begin{tabular}{|l|c|c|c|}
\hline Ketuntasan & Interval & Frekuensi & Persentase (\%) \\
\hline Tuntas & $\geq 70$ & 20 & 83 \\
\hline Tidak tuntas & $\leq 69$ & 4 & 17 \\
\hline KKM & \multicolumn{3}{|c|}{} \\
\hline Nilai minimal & \multicolumn{3}{|c|}{40} \\
\hline Nilai maksimal & 90 \\
\hline
\end{tabular}

Hasil belajar siswa kelas 4 SD Negeri 2 Gunungtumpeng pada siklus II yang tuntas KKM adalah 20 siswa atau sebesar $83 \%$, sedangkan siswa yang belum tuntas KKM adalah 4 siswa atau sebesar $17 \%$. 
1325 Penerapan Model Discovery Learning dalam Pembelajaran IPA untuk Meningkatkan Kemampuan Berpikir Kritis dan Hasil Belajar Siswa Sekolah Dasar - Wahyu Candra Dwi Safitri, Nani Mediatati DOI: https://doi.org/10.31004/basicedu.v5i3.925

Analisis deskriptif komparatif data kemampuan berpikir kritis siswa kelas 4 pada siklus 1 dan siklus II menunjukkan hasil sebagai berikut.

Tabel 5. Analisis Deskriptif Komparatif Kemampuan Berpikir Kritis

\begin{tabular}{|c|l|c|c|c|c|}
\hline \multirow{2}{*}{ No } & \multirow{2}{*}{ Kategori } & \multicolumn{2}{|c|}{ Siklus 1 } & \multicolumn{2}{c|}{ Siklus II } \\
\cline { 3 - 6 } & & Jumlah & $\begin{array}{c}\text { Persentase } \\
(\boldsymbol{\%})\end{array}$ & Jumlah & $\begin{array}{c}\text { Persentase } \\
(\boldsymbol{\%})\end{array}$ \\
\hline 1 & Sangat tinggi & 0 & 0 & 13 & 54 \\
\hline 2 & Tinggi & 3 & 13 & 7 & 30 \\
\hline 3 & Sedang & 9 & 37 & 2 & 8 \\
\hline 4 & Rendah & 10 & 42 & 2 & 8 \\
\hline 5 & Sangat rendah & 2 & 8 & 0 & 0 \\
\hline \multicolumn{2}{|r|}{ Jumlah } & 24 & 100 & 24 & 100 \\
\hline \multicolumn{2}{|r|}{ Kesimpulan } & \multicolumn{2}{|c|}{ Berhasil berhasil } \\
\hline
\end{tabular}

Berdasarkan tabel 5 dapat dilihat bahwa ada peningkatan kemampuan berpikir kritis siswa dari siklus I ke siklus II. Siklus I menunjukkan bahwa siswa dengan kemampuan berpikir kritis kategori sangat tinggi tidak ada, kategori tinggi sebanyak 3 siswa atau sebesar 13\%, kategori sedang sebanyak 9 siswa atau sebesar 13\%, kategori rendah sebanyak 10 siswa atau sebanyak $42 \%$, kategori sangat rendah sebanyak 2 siswa atau sebesar $8 \%$. Berbeda dengan hasil siklus II yang menunjukkan bahwa siswa dengan kemampuan berpikir kritis kategori sangat tinggi sebanyak 13 atau sebesar 54\%, kategori tinggi sebanyak 7 siswa atau sebesar 30\%, kategori sedang sebanyak 2 siswa atau sebesar 8\%, kategori rendah sebanyak 2 siswa atau sebesar $8 \%$. Hasil analisis deskriptif komparatif kemampuan berpikir kitis mulai dari siklus I ke siklus II menunjukkan adanya peningkatan kemampuan berpikir kritis pada siswa kelas 4 SD Negeri 2 Gunungtumpeng.

Selanjutnya analisis deskriptif komparatif data ketuntasan hasil belajar siswa kelas 4 pada siklus 1 dan siklus II menunjukkan hasil sebagai berikut.

Tabel 6. Analisis Deskriptif Komparatif Hasil Belajar

\begin{tabular}{|c|l|c|c|c|c|}
\hline \multirow{2}{*}{ No } & \multirow{2}{*}{ Kategori } & \multicolumn{2}{|c|}{ Siklus 1 } & \multicolumn{2}{c|}{ Siklus II } \\
\cline { 3 - 6 } & & Jumlah & $\begin{array}{c}\text { Persentase } \\
(\mathbf{\%})\end{array}$ & Jumlah & $\begin{array}{c}\text { Persentase } \\
(\mathbf{\%})\end{array}$ \\
\hline 1 & Tuntas & 3 & 13 & 20 & 83 \\
\hline 2 & Tidak tuntas & 21 & 87 & 4 & 17 \\
\hline
\end{tabular}

Berdasarkan tabel 6, ketuntasan hasil belajar siswa dari siklus I dan siklus II menunjukkan peningkatan. Siswa yang tuntas melampaui KKM (70) pada siklus I sebanyak 3 siswa atau sebesar 13\%, dan yang tidak tuntas sebanyak 21 siswa atau sebanyak 87\%. Berbeda dengan siklus II, siswa yang tuntas KKM (70) sebanyak 20 siswa atau sebesar $83 \%$, dan yang tidak tuntas sebanyak 4 siswa atau sebesar $17 \%$.

Dengan demikian, penelitian yang dilakukan di SD Negeri 2 Gunungtumpeng dengan menerapkan model pembelajaran Discovery learning terbukti dapat meningkatkan kemampuan berpikir kritis dan hasil belajar siswa kelas 4 .

Berdasarkan hasil penelitian, diperoleh hasil bahwa ada peningkatan kemampuan berpikir kritis siswa sesudah diterapkan model pembelajaran Discovery learning. Hasil deskriptif komparatif kemampuan berpikir kitis mulai dari siklus I dan siklus II menunjukkan adanya peningkatan kemampuan berpikir kritis pada siswa kelas 4 SD Negeri 2 Gunungtumpeng. Siklus I menunjukkan bahwa kemampuan berpikir kritis siswa dengan kategori sangat tinggi tidak ada, kategori tinggi sebanyak 3 siswa atau sebesar 13\%, kategori sedang sebanyak 9 siswa atau sebesar 13\%, kategori rendah sebanyak 10 siswa atau sebanyak 42\%, kategori sangat rendah sebanyak 2 siswa atau sebesar 8\%. Berbeda dengan hasil siklus II yang menunjukkan bahwa kemampuan berpikir kritis siswa dengan kategori sangat tinggi sebanyak 13 atau sebesar 54\%, kategori tinggi sebanyak 7 siswa atau sebesar 30\%, kategori sedang sebanyak 2 siswa atau sebesar 8\%, dan kategori rendah sebanyak 2 
siswa atau sebesar $8 \%$. Ketuntasan hasil belajar siswa dari siklus I dan siklus II juga menunjukkan peningkatan. Siswa yang tuntas melampaui KKM (70) pada siklus I sebanyak 3 siswa atau sebesar 13\%, dan yang tidak tuntas sebanyak 21 siswa atau sebanyak $87 \%$. Berbeda dengan siklus II, siswa yang tuntas KKM (70) sebanyak 20 siswa atau sebesar 83\%, dan yang tidak tuntas sebanyak 4 siswa atau sebesar $17 \%$. Pada siklus 1 kemampuan berpikir kritis siswa masih banyak dalam kategori rendah dan kecil dalam kategori tinggi dan tidak ada dalam kategori sangat tinggi walaupun sudah diterapkan model pembelajaran discovery learning karena siswa kurang kondusif belajar melalui aplikasi daring, sehingga pembelajaran yang dilakukan guru belum maksimal. Selain itu kendala sinyal yang dimiliki beberapa siswa kurang bagus, sehingga penyampaian materi oleh guru kurang dicerna baik oleh siswa. Hal ini juga berpengaruh terhadap hasil belajar siswa masih banyak yang belum tuntas. Namun setelah dilakukan perbaikan pada siklus II dengan penerapan tata tertib penggunaan microphone ketika ingin menjawab atau bertanya, akses materi yang dapat dibuka melalui google drive, serta penggabungan beberapa siswa di tempat yang memiliki sinyal bagus, kemampuan berpikir kritis siswa meningkat pada kategori sangat tinggi dan tinggi mencapai $84 \%$ serta ketuntasan hasil belajar mencapai 83\% melampaui indikator keberhasilan dari penelitian ini.

Hasil penelitian ini juga mendukung penelitian (Ratih Dwi Yulianti Rahayu, Mawardi, 2019) dengan judul "Peningkatan Kemampuan Berpikir Kritis dan Hasil Belajar Siswa Kelas 4 SD melalui Model Pembelajaran Discovery learning" yang dilakukan di SD N Karangduren 02 menunjukkan peningkatan keterampilan kritis dan hasil belajar siswa. Pada pra siklus, keterampilan berpikir kritis kategori sangat tinggi sebesar 7\%, kategori tinggi 41\%, dan kategori rendah 52\% sehingga berdampak pada hasil belajar dengan persentase $46 \%$ mencapai ketuntasan dan $64 \%$ belum mencapai ketuntasan. Siklus I, keterampilan berpikir kritis siswa meningkat menjadi 22\% kategori sangat tinggi, 63\% kategori tinggi, dan $15 \%$ kategori rendah. Hasil belajar siswa $63 \%$ mencapai ketuntasan dan $37 \%$ belum mencapai ketuntasan. Selanjutnya, pada siklus II meningkat lebih signifikan yakni 63\% kategori sangat tinggi, dan 37\% kategori tinggi. Hasil belajar 85\% mencapai ketuntasan dan $15 \%$ belum tuntas.

Senada juga dengan penelitian (Windarti et al., 2018) dengan judul "Peningkatan Kemampuan Berpikir Kritis serta Hasil Belajar melalui Penerapan Model Discovery learning dalam Pembelajaran Tematik Kelas 4" membuktikan penerapan model Discovery learning dapat meningkatkan kemampuan berpikir kritis serta hasil belajar. Persentase kemampuan berpikir kritis pada kategori sangat tinggi, tinggi, dan sedang pada siklus I adalah $30 \%$, meningkat pada siklus II menjadi $82 \%$. Ketuntasan hasil belajar siswa pada pra siklus adalah $38 \%$, meningkat menjadi $68 \%$ pada siklus I, dan kembali mengalami peningkatan $85 \%$ pada siklus II. Penelitian lainnya yakni (Mahartati, 2017) yang berjudul "Meningkatkan Motivasi dan Hasil Belajar Tematik Peserta Didik dengan Mengoptimalkan Penerapan Model Discovery Learning di SD Negeri 3 Cakranegara" dinyatakan berhasil. Siklus II menunjukkan hasil observasi guru pada pertemuan kedua mendapat skor ratarata 4,29 dan hasil observasi siswa pertemuan kedua mendapat skor rata-rata 4,13. Selanjutnya, dampak dari peningkatan motivasi belajar adalah perolehan hasil belajar yang meningkat. Siswa mencapai nilai rata-rata 81,43 sehingga indicator keberhasilan > 4,0 dan hasil belajar > 75,00 telah terlampaui.

Hasil penelitian yang hampir sama dengan penelitian ini yakni penelitian (Windi Oktaviani, Firosalia Kristin, 2018) dengan judul "Penerapan Model Pembelajaran Discovery Learning untuk Meningkatkan Kemampuan Berpikir Kritis dan Hasil Belajar Matematika Siswa Kelas 5 SD”. Berdasarkan hasil penelitian yang dilakukan di SD Negeri 3 Nambuhan, Kecamatan Purwodadi Kabupaten Grobogan, diperoleh hasil bahwa model Discovery Learning dapat meningkatkan kemampuan berpikir kritis dan hasil belajar Matematika. Hasil analisis data kemampuan berpikir kritis siswa menunjukkan rata-rata pra siklus sebesar 54, kemudian siklus I meningkat menjadi 68, dan siklus II meningkat menjadi 78. Selanjutnya hasil analisis data hasil belajar menunjukkan bahwa pada pra siklus tingkat ketuntasan sebesar 34,61\%, siklus 1 sebesar 73,07\%, dan siklus II sebesar $84,62 \%$. Kemampuan berpikir kritis siswa ditunjukkan dari hasil pra siklus sebesar $26,92 \%$, siklus I sebesar 73,07\%, dan siklus II sebesar 84,62\%. Hal ini sejalan dengan penelitian (Nichen Irma 
1327 Penerapan Model Discovery Learning dalam Pembelajaran IPA untuk Meningkatkan Kemampuan Berpikir Kritis dan Hasil Belajar Siswa Sekolah Dasar - Wahyu Candra Dwi Safitri, Nani Mediatati DOI: https://doi.org/10.31004/basicedu.v5i3.925

Cintia, Firosalia Kristin, 2018) dengan judul "Penerapan Model Pembelajaran Discovery Learning untuk Meningkatkan Kemampuan Berpikir Kreatif dan Hasil Belajar Siswa yang dilakukan di SD Negeri Sidorejo Kidul 02 Kecamatan Tingkir, menyatakan bahwa model Discovery Learning dapat meningkatkan kemampuan berpikir kreatif dan hasil belajar siswa kelas V. Kondisi awal persentase kemampuan berpikir kreatif sebesar $33,2 \%$ dengan skor rata-rata 13,3. Ketuntasan hasil belajar sebesar 38\%, dengan rata-rata 60, nilai tertinggi 72,5 dan terendah 45. Siklus 1 menunjukkan kemampuan berpikir kreatif siswa $73 \%$ dengan skor rata-rata 29,2. Persentase hasil belajar 71,8\% dengan rata-rata 69,48 serta nilai tertinggi 82,5 dan nilai terendah 50 . Sedangkan siklus II menunjukkan persentase kemampuan berpikir kreatif sebesar 81,2\% dengan rata-rata 32,2. Hasil belajar 84,6\% dengan rata-rata 74,2, nilai tertinggi 87,5 dan terendah 55 .

\section{KESIMPULAN}

Berdasarkan hasil penelitian, maka dapat disimpulkan bahwa dengan menerapkan model Discovery learning dalam pembelajaran IPA dapat meningkatkan kemampuan berpikir kritis dan hasil belajar siswa kelas 4 SD Negeri 2 Gunungtumpeng. Kemampuan berpikir kritis siswa dan ketuntasan hasil belajar siswa yang melampaui KKM (70) meningkat dari siklus I ke siklus II. Dengan demikian, model pembelajaran Discovery learning dapat dijadikan alternatif model pembelajaran yang digunakan oleh guru dalam pembelajaran di seklah dasar. Selain itu, dengan penerapan model Discovery learning siswa dapat mengembangkan kemampuan berpikir kritisnya dalam menghadapi berbagai permasalahan yang ada dalam kehidupan sehari-hari.

\section{DAFTAR PUSTAKA}

Ana, N. Y. (2019). Penggunaan Model Pembelajaran Discovery Learning Dalam Peningkatan Hasil Belajaran Siswa Di Sekolah Dasar. Pedagogi: Jurnal Ilmu Pendidikan, $18(2), \quad 56$. https://doi.org/10.24036/fip.100.v18i2.318.000-000

Arfika Wedekaningsih, Henny Dewi Koeswanti, S. G. (2019). Jurnal basicedu. Jurnal Basicedu, 3(1), 21-26.

Fahrurrozi, S. H. (2017). Metode Pembelajaran Matematika Inovatif. In Universitas Hamzanwadi Press. https://febriliaanjarsari.wordpress.com/2013/01/21/metode-pembelajaran-matematika-inovatif/

Kristin, F. (2016). Efektivitas Model Pembelajaran Kooperatif Tipe Stad Ditinjau Dari Hasil Belajar Ips Siswa Kelas 4 Sd. Scholaria: Jurnal Pendidikan Dan Kebudayaan, 6(2), 74 https://doi.org/10.24246/j.scholaria.2016.v6.i2.p74-79

Larasati, D. A. (2020). Pengaruh Model Discovery Learning Berbasis Higher Order Thinking Skill Terhadap Kemampuan Berpikir Kritis. VOX EDUKASI: Jurnal Ilmiah Ilmu Pendidikan, 11(1), 39-47. https://doi.org/10.31932/ve.v11i1.684

Maharani, B. Y., \& Hardini, A. T. A. (2017). Penerapan Model Pembelajaran Discovery Learning Berbantuan Benda Konkret Untuk Meningkatkan Hasil Belajar Ipa. E-Jurnalmitrapendidikan, 1(5), 549-561.

Mahartati, I. G. (2017). Meningkatkan Motivasi dan Hasil Belajar Tematik Peserta Didik dengan Mengoptimalkan Penerapan Model Discovery Learning di SD Negeri 3 Cakranegara I. Jurnal Kependidikan, LPPM IKIP Mataram, 16(3), 245-250.

Nichen Irma Cintia, Firosalia Kristin, I. A. (2018). PENERAPAN MODEL PEMBELAJARAN DISCOVERY LEARNING UNTUK MENINGKATKAN KEMAMPUAN BERPIKIR KREATIF DAN Nichen Irma Cintia, Firosalia Kristin, I. A. (2018). PENERAPAN MODEL PEMBELAJARAN DISCOVERY LEARNING UNTUK MENINGKATKAN KEMAMPUAN BERPIKIR KREATIF DAN HASIL . 32(1), 69-77.

Nurmayani, N. (2018). Penggunaan Model Pembelajaran Word Square Untuk Meningkatkan Hasil Belajar Siswa Pada Pelajaran Pendidikan Kewarganegaraan Di Kelas V Sd Negeri 054938 Kab. Langkat. School 
1328 Penerapan Model Discovery Learning dalam Pembelajaran IPA untuk Meningkatkan Kemampuan Berpikir Kritis dan Hasil Belajar Siswa Sekolah Dasar - Wahyu Candra Dwi Safitri, Nani Mediatati DOI: https://doi.org/10.31004/basicedu.v5i3.925

Education Journal Pgsd Fip Unimed, 8(1), 35-47. https://doi.org/10.24114/sejpgsd.v8i1.9781

Nurul Istikomah, S. C. R. A. T. A. H. (2018). Penerapan Model Discovery Learning Pada Pembelajaran Ips Untuk Meningkatkan Keaktifan Dan Hasil Belajar Kognitif Siswa Sekolah Dasar. Jurnal Didaktika Dwija Indria (SOLO), 6(3), 130-139.

Prameswari, S. W., Suharno, S., \& Sarwanto, S. (2018). Inculcate Critical Thinking Skills in Primary Schools.

Social, Humanities, and Educational Studies (SHEs): Conference Series, 1(1), 742-750. https://doi.org/10.20961/shes.v1i1.23648

Ratih Dwi Yulianti Rahayu, Mawardi, S. A. (2019). Peningkatan Keterampilan Berpikir Kritis Melalui Model

Pembelajaran Discovery Learning. Jurnal Penelitian Pendidikan IPA, 4(2), 8-13. https://doi.org/10.29303/jppipa.v1i2.20

Setianingrum, S., \& Wardani, N. S. (2018). Upaya Peningkatan Hasil Belajar Tematik Melalui Discovery Learning Siswa Kelas 1 Sekolah Dasar. Jurnal Pendidikan Dasar, 9(2), 149-158.

Windarti, Y., Slameto, S., \& Widyanti S, E. (2018). Peningkatan Kemampuan Berpikir Kritis Dan Hasil Belajar Melalui Penerapan Model Discovery Learning Dalam Pembelajaran Tematik Kelas $4 \mathrm{Sd}$. Pendekar : Jurnal Pendidikan Berkarakter, 1(1), 150. https://doi.org/10.31764/pendekar.v1i1.353

Windi Oktaviani, Firosalia Kristin, I. A. (2018). PENERAPAN MODEL PEMBELAJARAN DISCOVERY LEARNING UNTUK MENINGKATKAN KEMAMPUAN BERPIKIR KRITIS DAN HASIL BELAJAR MATEMATIKA SISWA KELAS 5 SD. Jurnal Basicedu, 2(2), 5-10. 